\title{
Factors Influencing Sexual Behavior among Female Adolescents in Onitsha, Nigeria
}

\author{
Ifeoma Bridget Udigwe1, Prosper Obunikem Adogu1 ${ }^{*}$, Achunam Simeon Nwabueze1, \\ Echendu Dolly Adinma1, Chika Florence Ubajaka1, Chika Onwasigwe ${ }^{2}$ \\ ${ }^{1}$ Department of Community Medicine \& Primary Health Care (PHC), Nnamdi Azikiwe University Teaching \\ Hospital (NAUTH), Nnewi, Nigeria \\ ${ }^{2}$ Department of Community Medicine, University of Nigeria Teaching Hospital (UNTH), Enugu, Nigeria \\ Email: prosuperhealth@yahoo.com
}

Received 18 September 2014; revised 15 October 2014; accepted 8 November 2014

Copyright (C) 2014 by authors and Scientific Research Publishing Inc.

This work is licensed under the Creative Commons Attribution International License (CC BY). http://creativecommons.org/licenses/by/4.0/

(c) (i) Open Access

\begin{abstract}
Background: The sexual health indices of the adolescents are very poor. This study ascertained the factors influencing the sexual behaviour among female adolescents in Onitsha, Anambra state, Nigeria. Method: This was a cross sectional design in which a total of 800 female adolescents were selected from secondary schools in the area using multistage sampling method; and also selected from a major market (for those who were not at school) in the same geographical area using cluster sampling technique. Data were collected from the respondents about socio-demographic profile, reproductive and sexual health knowledge, attitude, behavior, sources of sexual health information. Result: The highest proportion of students who had ever had sex was found among the 16 17 years age group while the modal age group was 18 - 19 years for non students. Also "not living with both parents" and poor family background, were markedly associated with increased likelihood to engage in sexual activity. Poverty level was particularly high among the non-student adolescents. Furthermore, wrong knowledge of fertile period, low risk perception of HIV and premarital, and use of condoms among the respondents were all significantly associated with increased chance to engage in sex. The student adolescents got sexuality information mainly from the teachers; as opposed to their non-student counterparts who had youth organization and friends as main sources. Conclusion: Family values, poverty alleviation, change of attitude through appropriate health and sexuality education especially targeting the non-student adolescents are highly recommended. Sexual negotiation skill, accessible formal education for all should be encouraged to create the right sexual behavior among the adolescent girls.
\end{abstract}

\section{Keywords}

Sexual Behavior, Female Adolescent Students, Non-Students, Onitsha, Nigeria

\footnotetext{
${ }^{*}$ Corresponding author.
} 


\section{Introduction}

Socio-economic factors such as family size, income, type of housing and housing environment, social value, nature of job, affect the sexual behaviour of adolescents. A study carried out in Ibadan reported that poverty, lack of parental monitoring and parents working long hours push the adolescents especially the out-of-school ones into unnecessary sexual relationships [1]. It reported that children from poor homes are likely to be street children, hawkers and more likely to live in a neighborhood that will influence them negatively. The non-student adolescents are most often found in such conditions and therefore more vulnerable to early sexual exposures compared to their student counterparts.

Some studies support the proposition that adolescents are less likely to engage in sexual risk-taking behaviour when they reside with a parent especially two parents or when they identify with the views of their parents. A study carried out in Lagos among out-of-school female adolescents reported that more than 60\% of those who reside with relatives or friends were sexually active compared to those who lived with both or either parents (38\%) [2]. There is growing evidence that various parenting dimension-connectedness or love, material support, behavioural control or monitoring and parent child communication are positively associated with reduced levels of risk-taking behaviour among adolescents. A survey based study in a slum in Kenya, found that when a father lived in the same household as his never married daughters, they were much less likely to have had sex than when neither parent nor only the mother lived in the household [3]. In Ghana, [4] and Cote d' Ivoire [3] they reported that adolescent females who lived with both parents were less likely than females who had other living arrangements to have ever had sex, though, the same was not found for males. Two parents are more likely to provide a best emotional support and life lessons necessary for a child's development and psychosocial adjustment. Also, adolescents living in two parent families take advantages of the presence of their parents in the home and can internalize from both father and mother about heterosexual love and commitment [5] [6]. Research has also shown that adolescents whose parents are not married have a tendency to believe that premarital sexual intercourse is socially acceptable and thereafter to initiate sexual intercourse prematurely. Other causes of family instability such as divorce, remarriage, parental death and mother-only families have been reported to increase the likelihood of sexual initiation among adolescents. These conditions are reportedly more prevalent among the out-of-school females compared to their in-school counterparts [3].

Parents are the primary socializers of their children. They are in a unique position to help adolescents have responsible attitudes and behaviour towards sex, and to educate adolescents into healthy sexual habits. A study of the sexual behaviour of adolescents in Nigeria reported that low educational level of parents were associated with increased risky sexual behaviour among them. A study also carried out among adolescents in Ibadan, agreed that parental educational level significantly affect the sexual behaviour of their children. The author reported that children from highly educated home and conducive environment are prone to good behaviour and acceptable norms and values of the society than children from illiterate homes and poverty ridden homes. This finding is consistent with studies carried out among American adolescents where it was reported that higher levels of parental education have been associated with lower adolescent sexual activity, delay of intercourse initiation, greater use of contraception and lower risk of pregnancy. It is expected that parents with sound education exposure will direct their children towards positive sexual behavior.

Poverty is probably the underlying factor in most risky sexual behaviours. Poverty will lead to lack of education which may reduce earning power and lack of parental monitoring, and these may in turn lead to transactional sex, transgenerational sex or pursuit of multiple sexual partners. A growing body of evidence points to the complexity of sexual behaviour. Sexual risk behaviour is influenced by factors at three levels; within the person, within the proximal context (interpersonal relationships and physical and organizational environment) and within the distal context (cultural and structural factors). The pervasive effects of poverty and social norms perpetuate women' subordination within sexual relationships [7]. Poverty motivates both young males and females to engage in risky sex. According to a study from Bamenda Cameroun, those whose fathers were unemployed and those who lived in poor households were more likely to have multiple sexual partners. Furthermore young people who did not live with both parents and had insufficient means were more likely to have multiple sexual partners [8]. Out of school girls especially those who hawk on the streets or live on the streets fall into the last group. A study among out-of-school girls in Nigeria reported that almost half of the respondents were expected to find the means to supplement the funds they were given to meet their basic needs and most of them were found to be sexually active [2]. The economic circumstances in many developing countries have made the tran- 
sition of young people into healthy adults difficult and may explain why transactional sex is common among female adolescents. Looking at it from the context of HIV/AIDS evidence from South Africa showed that women from poorer households were slightly less knowledgeable about HIV/AIDS [9]. Another study from Uganda showed that financial pressures play a major role in influencing out-of-school girls to begin engaging in sex in order to meet basic needs. For girls out-of-school and not living with their parents, basic needs could be as basic as a meal or two [10]. Studies from 3 African countries showed that the wealthiest girls had later sexual debut compared to their poor counterparts, they are also more likely to have protected sex [11]. In another study, females from poorer households were more likely to be sexually active and more likely to engage in risky sexual behaviour [12]. However, even in situations where poverty is prevalent there are modulating factors that may affect sexual behaviour. Interventions with parents and other guardians to increase monitoring and communication about sex and sexual risks seem to be promising health promotion strategies for adolescent high risk setting [13]. Even in a liberal society like the United States, parenteral monitoring and communication appeared able to influence sexual activity positively [14].

This study therefore examined the factors influencing sexual activity among female adolescents in Onitsha, Anambra State, Nigeria

\section{Methods}

Design and study area: A cross-sectional study of unmarried female secondary school student adolescents and non student adolescents aged 10 - 19 years residing in Onitsha, Anambra State. The Onitsha main market and other surrounding satellite markets constituted the setting where the non-student female adolescents were recruited for this study. Also the Onitsha North LGA has 25 private schools and 17 public schools, giving a total of 42 schools. They are 22 co-educational schools, 12 boys’ only schools and 8 girls' only schools. The female student adolescent participants were recruited from these schools. Adolescents with hearing loss, speech and mental disabilities were excluded.

Sampling technique: Secondary schools in the state were stratified into 4 categories as follows: 2 Femaleonly private, 6 female-only public, 17 mixed private and 5 mixed public schools. From each of the strata, one school was selected using stratified random sampling technique. From each selected school, 100 respondents were selected using stratified random sampling, giving a total of 400 respondents, but response rate was however 97.8\%. Unmarried non-student female adolescents in the market were selected using cluster sampling technique as was done in previous studies [15] [16]. The market is estimated to have more than 60 clusters. Clusters of 30 were randomly selected from the sampling frame containing the list of all the clusters twice [17]. Using the WHO cluster sampling method, seven consenting adolescents were selected from each cluster until a total of 400 respondents was reached. Since the clusters were in different directions, a bottle was spun on the ground and the direction of its mouth was used to show the starting point for the study.

Instruments/methods of data collection: Pre-tested interviewer-administered questionnaires were used to collect information on variables such as: demographic characteristics, pattern of sexual practices/behavior and outcome.

Data analysis: SPSS version 17 statistical software was used for data entry and analysis. The Chi $\left(\mathrm{X}^{2}\right)$ square statistical test was used to compare proportions and evaluate associations. Differences and associations yielding $\mathrm{p}$ values of less than 0.05 was considered statistically significant $(\mathrm{p} \leq 0.05)$

\section{Ethical Consideration and Permission}

Ethical clearance was secured from the Ethics Committee of the Nnamdi Azikiwe University Teaching Hospital Nnewi. Official permission was also obtained from Anambra State Education Commission, Onitsha North Local Government authorities, each selected school authority and the authorities in charge of the market. Informed consents were obtained from the adolescents' parent/guardian especially for non-student respondents and from all respondents after explaining the purpose, objectives and benefits of the research to them. They were assured of no harm in participation and were told that participation is entirely voluntary.

\section{Result}

There were 800 female adolescents in our research. The result of their responses is summarized in figures and 
tables below.

Figure 1 shows common reasons for first sexual intercourse. The most common reason for both groups was pressure from partner or boyfriend. However, more of the student adolescents (29.3\%) were engaged in transactional sex, while more of their non-student counterparts were forced or coerced into sex (19.2\%).

According to Table 1, sexual practice among the girls was statistically significantly associated with age $\left(\chi^{2}=\right.$ 22.43, $\mathrm{p}=0.0001)$, whom they lived with most of the time $\left(\chi^{2}=11.11, \mathrm{p}=0.025\right)$ and family living condition $\left(\chi^{2}=4.79, \mathrm{p}=0.091\right)$.

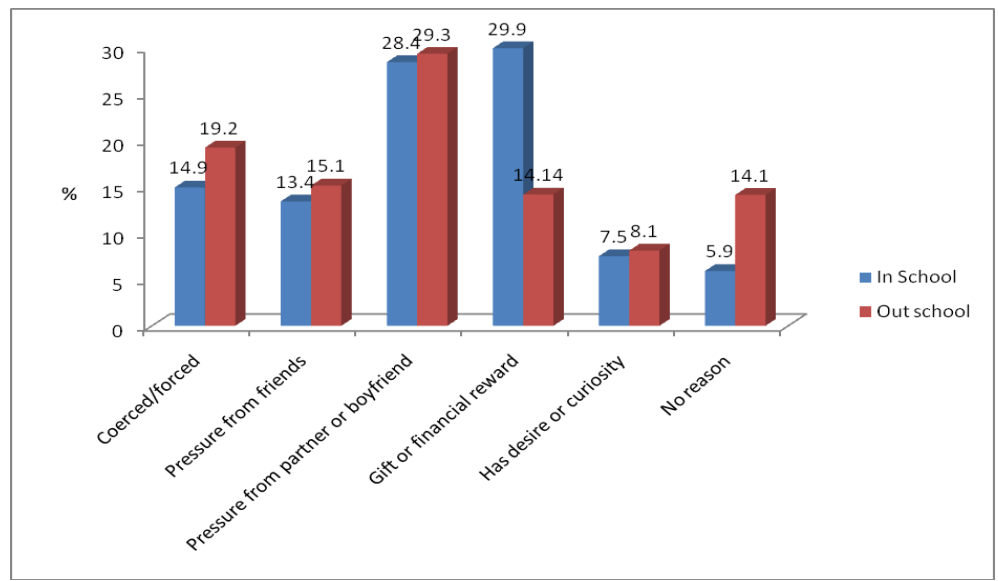

Figure 1. Reasons for first sexual intercourse.

Table 1. "Ever had sex" by socio-demographic characteristics of the respondents.

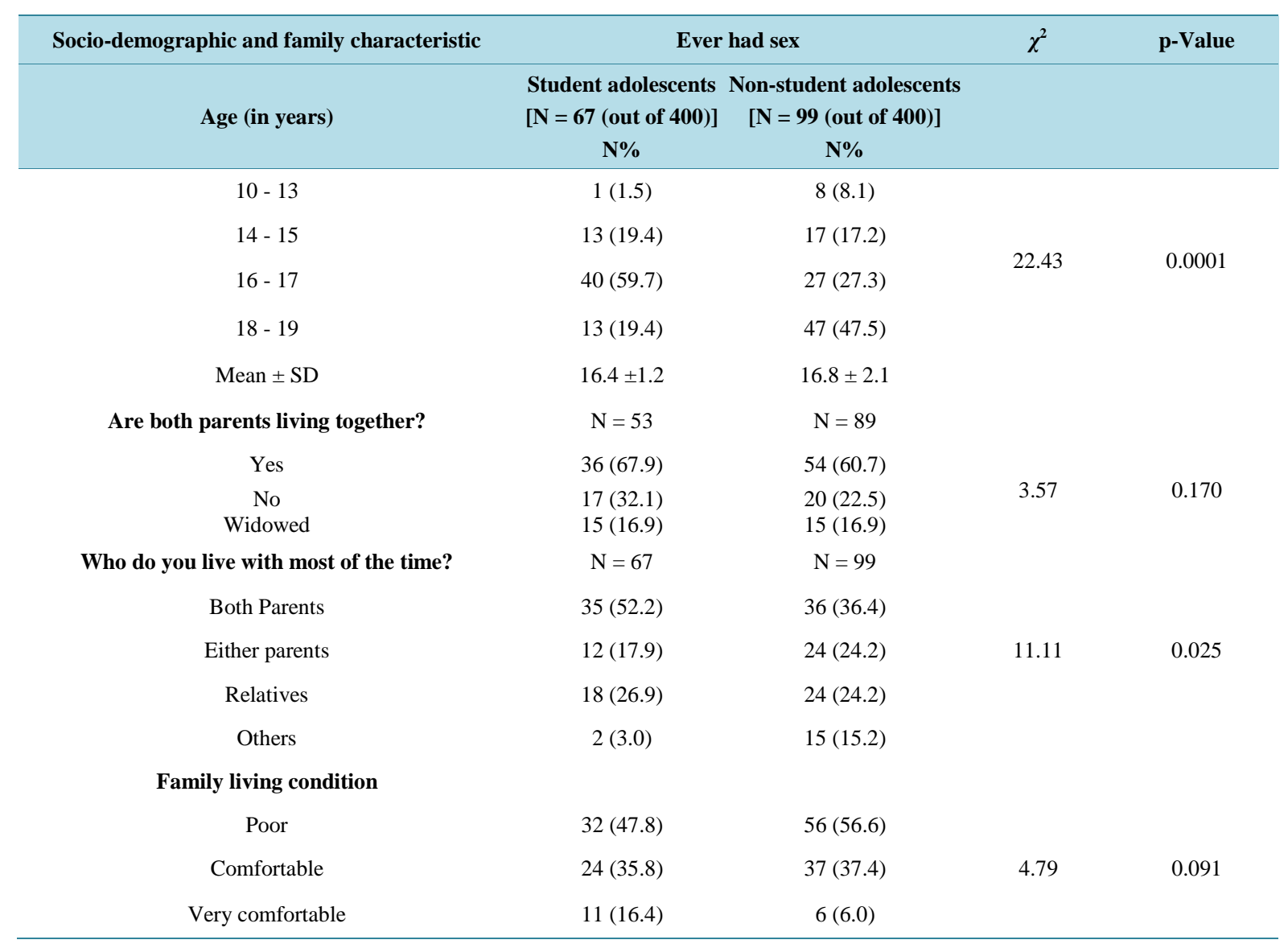


Table 2 shows that the likelihood to have ever engaged in sex is significantly increased with wrong knowledge of fertile period $\left(\chi^{2}=15.23, \mathrm{p}=0.009\right)$, knowledge of STIs $\left(\chi^{2}=21.46, \mathrm{p}=0.0001\right)$ and knowledge of HIV transmission $\left(\chi^{2}=3.83, \mathrm{p}=0.050\right)$ and prevention $\left(\chi^{2}=38.08, \mathrm{p}=0.0001\right)$.

Table 3 indicates that wrong attitude towards premarital sex, low or no HIV-associated risk perception and

Table 2. Knowledge of some RH issues among in-school and out-of-school respondents who had ever had sex.

\begin{tabular}{|c|c|c|c|c|}
\hline \multirow{2}{*}{\begin{tabular}{|c|} 
Sexual health knowledge \\
Correct knowledge of fertile period
\end{tabular}} & \multicolumn{2}{|c|}{ Ever had sex } & \multirow[t]{2}{*}{$\chi^{2}$} & \multirow[t]{2}{*}{ p-Value } \\
\hline & $\begin{array}{c}\text { Student adolescents } \\
[\mathrm{N}=67 \text { (out of } 400)] \\
\mathrm{N} \%\end{array}$ & $\begin{array}{c}\text { Non-student adolescents } \\
\text { [N = } 99 \text { (out of 400)] } \\
\text { N\% }\end{array}$ & & \\
\hline Yes & $24(35.8)$ & $20(20.2)$ & 15.23 & 0.009 \\
\hline No & $43(64.2)$ & $79(79.8)$ & & \\
\hline \multicolumn{5}{|l|}{ Knowledge of any contraception methods } \\
\hline Yes & $37(55.2)$ & $92(92.9)$ & 21.46 & 0.0001 \\
\hline No & $30(44.8)$ & $7(7.1)$ & & \\
\hline \multicolumn{5}{|c|}{ Knowledge of at least one mode of HIV transmission } \\
\hline Yes & 60 (89.6) & $93(93.9)$ & 3.83 & 0.050 \\
\hline No & $7(10.5)$ & $6(6.1)$ & & \\
\hline \multicolumn{5}{|c|}{ Knowledge of at least one method of HIV prevention } \\
\hline Yes & $52(77.6)$ & $30(30.3)$ & 38.08 & 0.0001 \\
\hline No & $15(22.4)$ & $69(69.7)$ & & \\
\hline
\end{tabular}

Table 3. Relationship between "ever had sex" and attitude, risk perception of the girls.

\begin{tabular}{|c|c|c|c|c|}
\hline \multirow[b]{2}{*}{ Attitude and risk perception } & \multicolumn{2}{|c|}{ Ever had sex } & \multirow[b]{2}{*}{$\chi^{2}$} & \multirow[b]{2}{*}{ p-Value } \\
\hline & $\begin{array}{c}\text { Student adolescents } \\
\text { [N = 67 (out of 400)] } \\
\text { N\% }\end{array}$ & $\begin{array}{c}\text { Non-student adolescents } \\
\text { [N = 99 (out of 400)] } \\
\text { N\% }\end{array}$ & & \\
\hline \multicolumn{5}{|c|}{ Number of sex before one can get HIV infection } \\
\hline Once & $43(64.2)$ & $79(79.8)$ & & \\
\hline 2 - 5 times & $20(29.9)$ & $12(12.1)$ & 5.004 & 0.032 \\
\hline$>5$ times & $2(3.0)$ & $5(5.1)$ & & \\
\hline DNK & $2(3.0)$ & $3(3.0)$ & & \\
\hline \multicolumn{5}{|c|}{ Risk of acquiring HIV/HIV risk perception } \\
\hline None & 25 (37.3) & $24(24.2)$ & & \\
\hline Low & $15(22.4)$ & $17(17.1)$ & & \\
\hline Moderate & $4(6.0)$ & $5(5.1)$ & 7.52 & 0.057 \\
\hline High & $1(1.5)$ & $15(15.2)$ & & \\
\hline DNK & $22(32.8)$ & $38(38.4)$ & & \\
\hline \multicolumn{5}{|c|}{ A girl should have sexual experience before marriage } \\
\hline Agree & 20 (29.9) & $44(44.4)$ & & \\
\hline Disagree & $40(59.7)$ & $40(40.4)$ & 6.52 & 0.038 \\
\hline DNK/Unsure & $7(10.5)$ & $15(15.2)$ & & \\
\hline \multicolumn{5}{|c|}{ Unmarried couples should use condom during sex } \\
\hline Agree & $27(40.3)$ & $57(57.6)$ & 5.546 & 0.025 \\
\hline Disagree & $31(46.3)$ & $29(29.3)$ & & \\
\hline DNK/Unsure & 9 (13.4) & $13(13.1)$ & & \\
\hline
\end{tabular}


use of condom during premarital sex were found to be significantly associated with an increased tendency to ever have sex.

Statistically significant association was demonstrated between "ever had sex" and source of sexual health information (Table 4). The student adolescent girls who had teachers as main source of information, and nonstudent girls who had friends as main source of sexual health information were more likely to have ever had sex.

\section{Discussions}

Sexual behaviour in both groups of adolescents is influenced by age because those within the age group, 16 - 17 years were found to be more sexually active among student adolescents but higher among 18 - 19 years age group of non-student adolescents. The adolescents who were not living with both parents and those who lived under poor family economic status also showed a greater tendency to engage in early sexual activity. This is similar to the findings of a study carried out in Ibadan which reported that poverty, lack, parents working long hours all tend to push the adolescents especially the out-of-school ones into unnecessary sexual relationships [1]. It reported that children from poor homes are likely to be street children, hawkers and more likely live in a neighborhood that will influence them negatively. The non-student adolescents are most often found in such conditions and therefore more vulnerable to early sexual exposures compared to the in-school adolescents.

Some studies support the proposition that adolescents are less likely to engage in sexual risk-taking behaviour when they reside with a parent especially two parents or when they identify with the views of their parents. A study carried out in Lagos among out-of-school female adolescents reported that more than $60 \%$ of those who reside with relatives or friends were sexually active compared to those who lived with both or either parents (38\%) [2]. Family connectedness has been reported to have beneficial effect on the sexual health of young people by decreasing the likelihood of sexual intercourse. Some studies agree with this [5] [6] [18]-[20] but some also reported that socio-economic status of family had no influence on adolescents sexual behavior [21]-[23]. As part of strategies to delay initiation and reduce risky sexual behaviors, parents have to be sensitized on the importance of providing a supportive home environment for their children and of maintaining strong ties with them.

Also wrong knowledge of fertile period and wrong attitude towards premarital sex were significantly associated with sexual behaviour of the adolescents. One's level of knowledge is evidently predictive of the sexual behavior of adolescents as the findings in this study show that the student adolescents with more knowledge of HIV/STI had reduced sexual activity and the same is applicable to those who display good attitude towards sexual practice. Studies done in Nigeria [2], Tanzania [24], Ghana [25], Uganda [15] totally agree with these findings. Encouraging unmarried couples to use condom before sex, willingness to get condom for partner and

Table 4. Relationship between "ever had sex” and sources of sex information of the girls.

\begin{tabular}{|c|c|c|c|c|}
\hline Source & Ever & had sex & $\chi^{2}$ & p-Value \\
\hline & $\begin{array}{c}\text { Student adolescents } \\
{[\mathbf{N}=67 \text { (out of 400)] }} \\
\text { N\% }\end{array}$ & $\begin{array}{c}\text { Non-student adolescents } \\
{[\mathrm{N}=99 \text { (out of 400)] }} \\
\text { N\% }\end{array}$ & & \\
\hline School teacher & 25 (37.3) & $5(5.1)$ & & \\
\hline Parents & $7(10.5)$ & $6(6.1)$ & & \\
\hline Youth organisation & $5(7.5)$ & $9(9.1)$ & & \\
\hline Media-TV/Radio/Magazine & $7(10.5)$ & $21(21.2)$ & 34.25 & 0.0001 \\
\hline Friends & $15(22.4)$ & $40(40.4)$ & & \\
\hline Boyfriend & $6(9.0)$ & $16(16.1)$ & & \\
\hline Health worker & $2(3.0)$ & $1(1.0)$ & & \\
\hline Others & $0(0.0)$ & $0(0.0)$ & & \\
\hline
\end{tabular}


non-regular engagement in sex were significantly associated with contraceptive use for both groups of adolescents. This is in contra-distinction to the result of some other studies which identified age, multiple partnership, regular engagement in sex and prior discussion with partner as significant predictors of contraceptive use [15] [26] [27].

The student respondents had received their information mainly from parents and school teachers, while out-of-school girls had received information from youth organization, parents and friends. It is consistent with results of similar studies done in Owerri [28], Benue [29] and in four other African countries [30]. In this study, in-school adolescents significantly had more knowledge of sexual health than out-of-school adolescents. Involvement in schools and plans to attend higher education are all related to less sexual risk-taking and lower pregnancy [31]. However, the adolescents' knowledge of many sexual health issues was poor as can be seen from the significant number of both groups who did not know their fertile period and had some misconceptions of HIV/AIDS.

The study revealed a significant relationship between the sources of information and sexual behavior. Those who had received main information from teachers and friends were more likely than others to have ever had sex. Only 2.9\% had received information from health workers. Information received from friends may not be credible and most times misleading [28] while parents shy away from giving the adequate information. Most of the respondents indicated desire to receive correct sexual education or information, preferably from their parents, youth-organization and health workers. Similar results in most studies carried out pointed out this fact [18] [28] [32].

In conclusion, the factors significantly influencing sexual behaviour of both groups included age, not living with the two parents, poor family condition, wrong knowledge of fertile period, wrong attitudes towards premarital sex and low or no risk perception of HIV. There was no significant difference between the student and non-student respondents in contraceptive usage. Most of the adolescents have had some form of information on sexual and reproductive issues, but still had poor knowledge of them. The non-student girls who mainly got information from youth organization, friends and media were more sexually active than the student girls who got information from parents and teachers. Both groups expressed increased desire for more and correct information, preferably from parents, teachers and heath workers.

It is therefore recommended that multiple youth friendly centers and youth organizations manned by health workers should be set up in places where non-student adolescents and youth may be found such as markets and parks. Services should include information, counseling and curative services. Also communicating health messages through entertainment, drama, songs or music, essay competition, debate and other youth media programmes can be effective. These should be carried out both in schools and places where non-student adolescents maybe found. Such programmes can be organized by youth organizations, Ministry of Education, Health and Youths in the churches, youth clubs, market places and schools especially during festive periods like Valentine's Day, Christmas and long vacation. It is hoped that the implementation of these programmes will engender more decent and acceptable sexual behavior among adolescents in Anambra state.

\section{Conflict of Interest}

None declared by the authors who have all substantially contributed to the research and manuscript.

\section{Authors' Contributions}

1. Ifeoma Bridget Udigwe: Study concept, research design, data collection and collation;

2. Prosper Obunikem Adogu: Data analysis, presentation and interpretation, manuscript preparation, general project supervision;

3. Achunam Simeon Nwabueze: Manuscript preparation, literature review, data collation;

4. Echendu Dolly Adinma: Manuscript preparation, data cleaning;

5. Chika Florence Ubajaka: Manuscript preparation;

6. Chika Onwasigwe: Project supervision, manuscript supervision and organization.

\section{References}

[1] Amoran, O.E. and Fawole, O. (2008) Parental Influence on Reproductive Health Behaviour of Youth in Ibadan, Nige- 
ria. African Journal of Medicine Medical Sciences, 37, 21-27.

[2] National Population Commission (NPC) and ICF Macro (2009) Nigeria Demographic and Health Survey 2008. National Population Commission and ICF Macro, Abuja.

[3] Biddlecom, A., Asare, K.A. and Bankole, A. (2009) Role of Parents in Adolescent Sexual Activity and Contraceptive Use in Four African Countries. International Perspectives on Sexual and Reproductive Health, 35, 72-81. http://dx.doi.org/10.1363/3507209

[4] Alan Guttmacher Institute (2006) Adolescents in Ghana. The Alan Guttmacher Institute, New York.

[5] Markham, C.M., Tortolero, S.R., Escoba, S.L., Parcel, G.S., Hamst, R. and Addy, R.C. (2003) Family Connectedness and Sexual Risk-Taking among Urban Youth Attending Alternate High Schools. Perspectives on Sexual and Reproductive Health, 85, 174-179. http://dx.doi.org/10.1363/3517403

[6] Miller, M.C. (2002) Family Influence on Adolescents' Sexual and Contraceptive Behavior. The Journal of Sex Research, 39, 22-26. http://dx.doi.org/10.1080/00224490209552115

[7] Eaton, L., Flishar, A.J. and Aaro, L.E. (2003) Unsafe Sexual Behaviour in South African Youths. Social Science Medicine, 56, 149-165. http://dx.doi.org/10.1016/S0277-9536(02)00017-5

[8] Rwange, M.J. (2003) Poverty and Sexual Risk Behaviour among Young People in Bamenda, Cameroon. African Population Studies, 18, 91-104.

[9] Booysen, F.R. and Summerton, J. (2002) Poverty, Risky Sexual Behaviour and Vulnerability to HIV Infection: Evidence from South Africa. Journal of Health, Population and Nutrition, 20, 285-288.

[10] Bohmer, L. and Kwambira, E. (2000) Socio-Economic Context and the Sexual Behaviour of Ugandan Out-of-School Youths. Culture, Health and Sexuality, 2, 269-285. http://dx.doi.org/10.1080/136910500422250

[11] Madise, N., Zulu, E. and Gera, J. (2007) Is Poverty a Driver for Risk Sexual Behaviour? Evidence from National Survey of Adolescents in Few African Countries. African Journal of Reproductive Health, 11, 83-98. http://dx.doi.org/10.2307/25549733

[12] Dinkelman, T., Lam, D. and Lerbbrandt, M. (2008) Linking Poverty and Income Shocks to Risky Sexual Behaviour: Evidence from a Panel Study of Young Adults in Cape Town. South African Journal of Economics, 76, S52-S74. http://dx.doi.org/10.1111/j.1813-6982.2008.00170.x

[13] Romer, D., Stenton, B., Galbrath, J., Feigelman, S. and Black, M.X. (1999) Parental Influence on Adolescent Sexual Behaviour on High-Poverty Settings. Archives of Pediatrics and Adolescent Medicine, 153, 1055-1062. http://dx.doi.org/10.1001/archpedi.153.10.1055

[14] Romer, D., Black, M., Ricando, I., Fergelman, S., Ilaljee, L., Galbrath, J., Nesbit, R., et al. (1994) Social Influences on the Sexual Behaviour of Youth at Risk for HIV Exposure. American Journal of Public Health, 84, 977-985. http://dx.doi.org/10.2105/AJPH.84.6.977

[15] Kipp, W., Diesfeld, H. and Ndyanabangi, B. (2004) Reproductive Health Behaviour among In-School and Out-ofSchool Youths in Kabarole District, Uganda. African Journal of Reproductive Health, 8, 55-67. http://dx.doi.org/10.2307/3583393

[16] National Population Commission (NPC) and ICF Macro (2009) Nigeria Demographic and Health Survey 2008. National Population Commission and ICF Macro, Abuja.

[17] Rosneo, B. (1995) Fundamentals of Biostatistics. Wadsworth Publishing House, California.

[18] Odeyemi, K., Onajole, A. and Ogunnowo, B. (2009) Sexual Behaviour and the Influencing Factors among out of School Females Adolescent in Mushin Market, Lagos, Nigeria. International Journal of Adolescent Medicine and Health, 21, 101-110. http://dx.doi.org/10.1515/IJAMH.2009.21.1.101

[19] Adu-Mireka, S. (2003) Family Communication about HIV/AIDS and Sexual Behavior among Secondary School Students in Accra Ghana. African Health Sciences, 3, 7-14.

[20] Fatusi, A.O. and Blum, R.W. (2008) Predictors of Early Sexual Initiation among a Nationally Representative Sample of Nigerian Adolescents. BMC Public Health, 8, 136. http://dx.doi.org/10.1186/1471-2458-8-136

[21] Batwala, V., Nuwaha, E., Mulogo, E., Bagenda, F., Bajunirwe, F. and Mirembe, J. (2006) Contraceptive Use among In-School and Out-of-School Adolescents in Rural South-West Uganda. East African Medical Journal, 83, 18-24.

[22] Lawgun, O.O. and Ranthula, R.M. (2010) Factors That Influence Attitude and Sexual Behaviours among Constituency Youth Workers in Oshara Region, Namibia. African Journal of Reproductive Health, 14, 55-69.

[23] Okonofua, E. (2007) New Research Findings on Adolescent Reproductive Health in Nigeria. African Journal of Reproductive Health, 11, 17-19.

[24] Kazaura, R. and Melkiory, C. (2009) Sexual Practices among Unmarried Adolescents in Tanzania. BMC Public Health, 9, 373. http://dx.doi.org/10.1186/1471-2458-9-373 
[25] Sallah, A.M. (2009) Sexual Behaviour and Attitude towards Condoms among Unmarried in School and Out-of-School Adolescents in a High HIV Prevalence Region in Ghana. International Quarterly of Community Health Education, 29, 167-181.

[26] Adebiyi, A.O. and Asuzu, M.C. (2009) Condom Use amongst Out-of-School Youth in a Local Government Area in Nigeria. African Health Sciences, 9, 92-97.

[27] Onayade, A.A., Abiona, T.C., Ugbala, C., Alozie, G. and Adetugi, O. (2008) Determinants of Consistent Condom Use among Adolescents and Young Adults Attending a Tertiary Education Institution in Ile-Ife, Nigeria. Nigerian Postgraduate Medical Journal, 15, 185-191.

[28] Nwangwu, W.E. (2007) The Internet as a Source of Reproductive Health Information among Adolescent Girls in an Urban City in Nigeria. BMC Public Health, 7, 354. http://dx.doi.org/10.1186/1471-2458-7-354

[29] Otoide, V.O., Oronsaye, F. and Okonofua, F.E. (2001) Sexual and Contraceptive Use among Secondary Students in Benin City, Nigeria. Journal of Obstetrics Gynaecology, 23, 261-265.

[30] Bankole, A., Biddlecom, A., Guiella, G., Singh, S. and Zulu, E. (2007) Sexual Behavior, Knowledge and Information Sources of Very Young Adolescent in Four Sub-Saharan African Countries. African Journal of Reproductive Health, 11, 28-43. http://dx.doi.org/10.2307/25549730

[31] Aderibigbe, S.A. and Araoye, M.O. (2008) Effect of Health Education on Sexual Behaviour of Students of Public Secondary Schools in llorin, Nigeria. European Journal of Scientific Research, 24, 33-41.

[32] Okonofua, F., Sedgh, G., Bankole, A., Imarhiagbe, C., Hussain, R. and Wulf, D. (2009) Meeting Young Women’s Sexual and Reproductive Health Needs in Nigeria. Alan Guttmacher Institute, New York. 
Scientific Research Publishing (SCIRP) is one of the largest Open Access journal publishers. It is currently publishing more than 200 open access, online, peer-reviewed journals covering a wide range of academic disciplines. SCIRP serves the worldwide academic communities and contributes to the progress and application of science with its publication.

Other selected journals from SCIRP are listed as below. Submit your manuscript to us via either submit@scirp.org or Online Submission Portal.
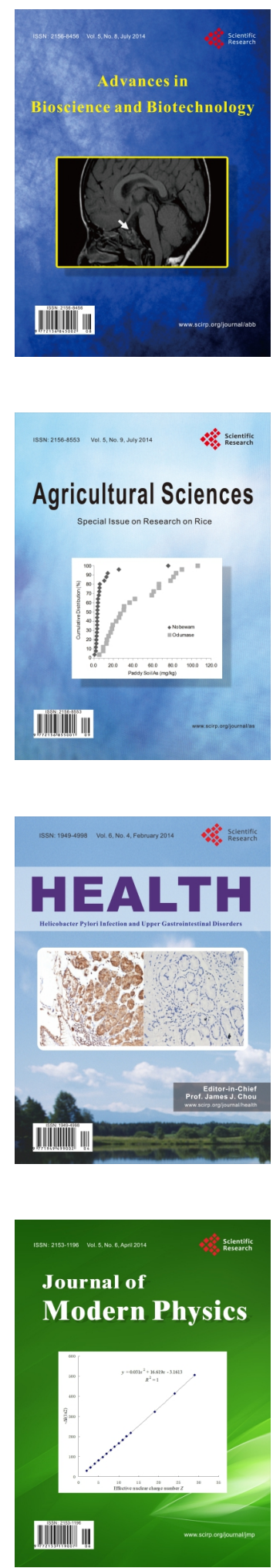
